\title{
Correlation Between Educational Performance, Family Background and Settlement Type in Covasna County, Romania
}

\author{
Andrea Barabás ${ }^{1}$, Katinka Bacskai \\ Recommended citation: \\ Barabás, A.- Bacskai K. (2020). Correlation Between Educational Effectiveness, Family Background and Settlement \\ Type in Covasna County, Romania. Central European Journal of Educational Research, 2(3), 62-69. https://doi.org/ \\ 10.37441/CEJER/2020/2/3/8531
}

\begin{abstract}
In social sciences, a more sophisticated way of examining students' school performance, based on the combination of school and family factors, is becoming increasingly popular. Important indicators of schools operating in a given territorial and societal context can be obtained both at student and institutional levels if territorial characteristics are included. In our research we examine the correlation between family background and performance, and investigate the settlement type where the proportion of students from low SES schools is the highest. At the same time we are also curious whether there is a greater chance of resilience in smaller communities. Our results show that the majority of students from low SES schools study in small settlements, but resilience is clearly not more typical in smaller communities.
\end{abstract}

Keywords: performance; family background; resilience

\begin{abstract}
Introduction
Romania's education system has undergone significant development over the past two decades, but this development has not affected all areas and social groups equally. In a significant part of the international measurements (eg TALIS), the Romanian education system performs very well, while in other measurements (eg PISA) it performs more poorly (Kitchen et al., 2017; Zoller \& Bacskai 2020). In our study, we would like to explore some of the reasons that lead to this imbalance. In social sciences, a more complex research method is emerging, which interprets students' school performance in the context of socio-family background and school effects. These studies base school performance on a combination of family and school factors. In the present study we aim to investigate the effect of settlement type in addition to family background factors. International and Hungarian competence measurements show that the correlation between students' school performance and socioeconomic status is strong (Barabás, 2019a, 2019b; Bradly \& Corwyn, 2002; Horn \& Keller \& Róbert 2016,; Pusztai, 2004, 2015; Széll, 2015). Past research shows that parents' level of education has a large impact on students' school performance. However, in addition to students' family background, the social composition of schools also significantly influences their results in the national Hungarian competence measurement (Bacskai, 2015; Széll, 2015; Fehérvári, 2016; Pusztai, 2009), in the national Romanian competency measurement (Barabás, 2020) or the PISA measurement (Pusztai \& Bacskai 2015). Assuming similar parental and school backgrounds, geographical features also play a major role in children's performance (Garami, 2014). The social environment of educational institutions is also of great importance. The Coleman report (1966), while examining the differences between schools, highlights that the difference is not the largest between schools of whites and blacks operating within a given area, but between different types of areas in the country. Large cities with agglomerations and rural areas differ greatly from each other (Kozma, 1988).
\end{abstract}

\footnotetext{
${ }^{1}$ University of Debrecen; andrea.barabas17@gmail.com

${ }^{2}$ University of Debrecen; bacskai.katinka@ arts.unideb.hu
} 
Schools in small settlements in Hungary simultaneously face the challenges of helping disadvantaged students catch up, ensuring talent management and providing quality education. In such an environment effectiveness becomes important from other points of view as well: the school's prestige, population retention power and its social integrating function come to the forefront. Family background also has an impact on school enrolment. Free school choice is utilized by middle-class or more educated parents. There is usually no other school in the settlement, thus parents enrol their children in the schools of nearby larger / urban settlements. Most often the high proportion of students of Roma origin in local schools motivates parents to take their children to a school in another municipality. However, this practice further complicates the situation of small settlement schools, not only resulting in a decrease in the number of staff, but also reinforcing segregation tendencies (Imre, 2004).

The performance of schools is an important indicator of the performance of the given territorial-social community, so the interdependence of the school and the settlement is more and more emphasized (Kozma, 1988). Though our data on this interdependence is rather incomplete, we encounter similar characteristics in our research and fieldwork. Social capital can be a link between in-school and out-of-school actors. Social capital plays a significant role in the cooperation between schools and within schools, in development efforts, in organizational learning and in problem solving. Among the examined external conditions of school operation the effect of poor family background is the strongest (Imre, 2004). The examination of school effectiveness also shows that the performance of schools may vary from class to class and from subject to subject in some schools. Educators, who deal with students from lower social status, use completely different methods than teachers who teach students with better family backgrounds (Zoller \& Bacskai, 2020). The family environment of students in low-status schools does not have adequate financial and cultural capital (Bacskai 2015), thus it must be compensated for by the school. Denominational schools are extremely active in compensating for this disadvantage. A higher proportion of low-status students from denominational grammar schools continue their studies in higher education than students of similar status from nondenominational schools (Pusztai, 2004). In order to have a deeper understanding of educational inequality, besides micro-level factors (characteristics of students' individual and family backgrounds), macro-level conditions (education system) and meso-level factors (school and its environment, type of settlement) also have to be taken into account. (Behtoui \& Neergaard, 2016; Ball, 2003).

The location of our research is Covasna County. Covasna County is in the south eastern part of Transylvania, and it is the most eastern county of the Carpathian Basin. It was created by the merge of the historical regions called Sepsi, Kézdi, Orbai and Miklósvár under the name of Háromszék, later renamed to Covasna. According to the 2011 census, this county has the lowest population in Romania, with only 210,000 inhabitants. Regarding ethnicity, $73.8 \%$ of the population of Covasna County is Hungarian, $23.3 \%$ is Romanian and approximately $3 \%$ is Roma.

Figure 1. and 2. Territorial location of Covasna county
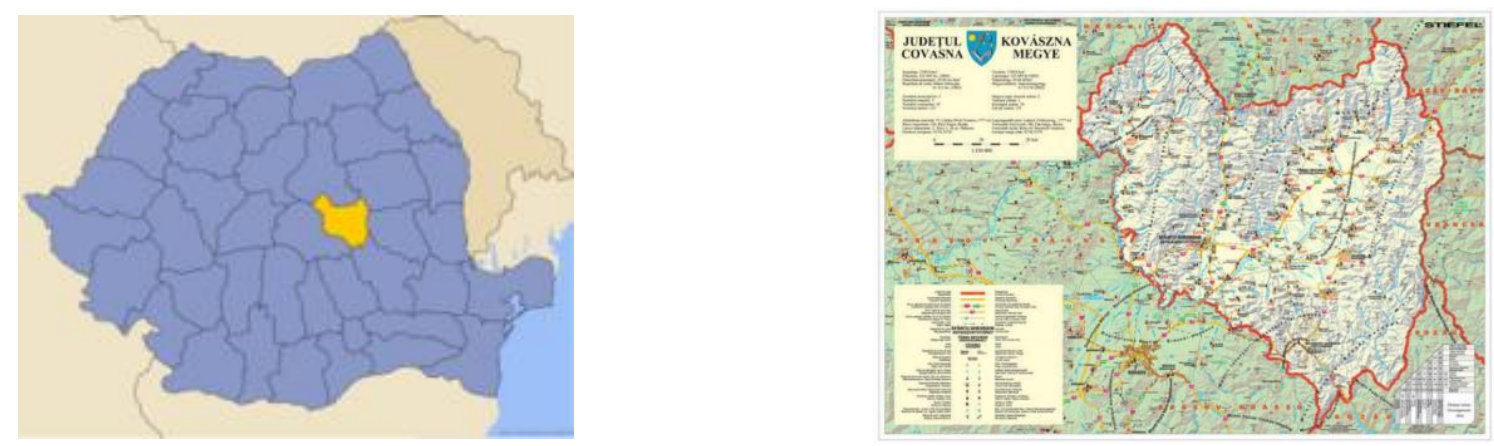

Source: http://wikimapia.org/34516305/hu/Kovászna-megye, http://transilvania-erdely.gportal.hu

The educational regulation mechanisms in Romania are characterized by input-output regulation: the input is regulated by the curriculum, the output is regulated by the examination requirements. The framework curriculum includes the number of hours of common, compulsory core material in elementary education and allows the introduction of optional subjects as part of the local curriculum, which can be not only independent, but also (integrated) or transdisciplinary (transdisciplinary) subjects (Potolea $\boldsymbol{\&}$ Manolescu, 2006; Barabás 2019a.). In Romania, the rate of early school leaving was $18.4 \%$ in 2010 and $17.4 \%$ in 2012 (Singer, 2013). The problems of early school leaving and the decreasing number of students (37,121 students in 2012 and 33,721 students in 2016 in all grades) are experienced in Covasna County as well. 
In connection with minority education, it is important to mention that the conditions of education are determined by the nation-state environment and education policies at the national level, but its characteristics are also influenced by systemic, institutional, individual and family factors (Papp Z., 2017). Education in the minority language contributes to the self-esteem of the minority and to the maintenance of its identity. The fight against assimilation is also constantly present, as merging into the majority would lead to the dissolution of the minority community (Papp Z., 2012). Minority education policy can be approached as a problem of social inequality. Minority education can lead either to the elimination or the increase of inequalities. There are components of socioeconomic background that can help or hinder school progress. They can carry important information in order to reduce the differences in performance caused by minority existence (Kozma, 2003).

Educational institutions in small settlements are in a more unfavorable position than most schools: the proportion of unemployed, low-educated parents and parents of Roma origin is higher. Research in Hungary shows that the Roma population is still in a significantly worse position in terms of education than the majority (Forrai \& Kozma, 2010). Census data are based on ethnic self-reports and do not provide accurate information on the "real" number of the Roma community. According to the municipalities, their proportion is three times higher than the number of those who profess to be Roma (Kiss \& Barna, 2013). Regarding the Hungarian minority in Romania, the number of its members is decreasing in all regions; however, the proportion of the Hungarian-speaking Roma population is very significant (Papp Z., 2017). In 2016 the Report of the World Bank shows that Covasna County has a very high poverty rate, which makes it the most vulnerable county in Romania's central region. We believe that the joint analysis of family, school and regional characteristics can reveal information that sheds light on the problems of Hungarian minority education. A study in Hungary, which examines the characteristics of settlement types, points out that small settlements are characterized by a low proportion of children in single-parent families, which may explain the more traditional perception of roles and families (Imre, 2004). At the same time, a high rate of unemployment and a low level of education are also characteristic of smaller settlements. Small and low SES schools also have poor human resources and equipment: both material and personal conditions are bad. However, they are effective from an educational and social point of view. Students from lower-status family backgrounds come to school with different levels of need, interest, and specific problems, so it is necessary to take a different approach in order to work with them effectively (Széll, 2018). Research also draws attention to the fact that schools in smaller settlements have a higher proportion of novice teachers, which is likely to be caused by greater fluctuation (Singer, 2013). Among teaching activities, in addition to the transfer of knowledge, personality development also plays a prominent role, which is manifested primarily in personal care for students. These skills are not usually acquired by teachers during their training but in school work (Pusztai, 2015).

If the different types of capital are successfully converted, among students with low socio-economic status there will be resilient ones and there will also be resilient schools. In our study, we examine resilient students / schools as a function of settlement type. The literature defines resilient students as students who perform well despite their disadvantage. They belong to the lowest group in terms of their family background, and to the highest in terms of their performance (Ceglédi, 2017). Resilient schools are those educational institutions that, despite their socially, economically and culturally disadvantaged student composition, achieve outstanding results in national competency measurements. At-risk schools have a socially, economically and culturally disadvantaged student population whose performance is poor (Széll, 2015).

\section{Research Design and Methods}

The residence of families is a very important circumstance. The educational institutions at the place of residence have a great influence on the child's future. In the present study we examine the correlation between educational effectiveness and settlement type. Is there a difference in the distribution of disadvantaged schools depending on the type of settlement? In which type of settlement do schools become more resilient? Is there a difference in resilience between different school subjects? In our study, we consider the results of the fourthgrade competence measurement as indicators of effectiveness, in three different measurement areas: Romanian language, Hungarian language and mathematics. The family background index was formed based on the parents' educational level and their financial assets. In our research, we consider resilient students and the rate of resilience per school as indicators of deviation from the expected value. We consider a student resilient if they belong to the low performance category based on the family background index, but their actual performance is significantly more positive than expected. With the help of this indicator, we can show the extent to which the 
school produces the expected performance based on the family background index at individual (student) and collective (school) levels.

We assume that the degree of resilience varies according to settlement types. Unfavourable regional conditions reinforce the effects of adverse family and school backgrounds on performance (Garami, 2014). The proportion of disadvantaged schools is higher in smaller settlements (Forray $\&$ Kozma, 2010; Bacskai, 2016). However, small rural schools are more likely to be resilient than urban ones. (Patakfalvi-Cirják, Papp Z. \& Neumann, 2018).

We present the results of the competency measurement of the 2016-17 academic year in which 1054 fourth-year students from 64 schools took part. The research was carried out in Transylvania, in Covasna County, which is mostly inhabited by Hungarians. The research examines the whole statistical population (no sampling involved). This means that every student who studies in Hungarian was asked. Also, a complete data collection was performed. We used the results of all students studying in Hungarian, similarly to the Hungarian National Competence Levelling Test. In schools we examined the performance of students and their family background at an institutional level as well. We can identify lagging / endangered and catching up / resilient schools.

The survey and the background questionnaire were filled in at the end of the school year, during the last week of May 2017, among Hungarian-speaking fourth graders. The results of the national measurement are based on codes and designed for evaluation at the task level. In our research, however, we do not want to evaluate students' performance at task level, but to examine factors influencing results. Since the results of the national levelling test are based on codes, point values have been assigned to the codes to allow statistical analysis of the results.

Thanks to the population sampling, we can get a comprehensive picture of the results of the 2017 fourth grade competence levelling test and the factors influencing these results. The Romanian Ministry of Education does not include in the test worksheet package a background questionnaire that can help to explore the influencing factors. In our research, we used a self-made background questionnaire. We base our research on the database created from the results of the background questionnaire and the competence test (KOV-ET-OM2017). The family background index we created includes parents' educational level, marital status, parents' employment characteristics, the number of books available at home and subjective well-being indicators. The positive deviation from the expected value is also analysed in our study.

\section{Results}

Regarding settlement types, Covasna county has one county seat, four towns and thirty-three villages. According to the 2011 census, approximately $40 \%$ of its population lives in towns and $60 \%$ in villages. If we analyse our examined sample as a function of types of settlement, we can state that $56.5 \%$ go to school in villages, while $43.5 \%$ pursue their studies in urban schools. In our research we found a significant correlation between the settlement type and low SES composition ( $\mathrm{P}=0.000$, adj, resid: 11). Of all students attending disadvantaged schools, $91.2 \%$ go to school in small settlements, while $8.8 \%$ study in urban disadvantaged schools.

Table 1. Relationships between settlement type and disadvantageous school composition

\begin{tabular}{lcc}
\hline & Village & City \\
\hline disadvantageous & $\underline{91.2 \%}$ & $8.8 \%$ \\
\hline non & $48.2 \%$ & $\underline{51.8 \%}$ \\
disadvantageous & & \\
\hline
\end{tabular}

$\mathrm{P}=0,000$, adj. resid: $11, \mathrm{~N}=1054$

Examining the three measurement areas, we found that $29.5 \%$ of the students were classified as high achieving in Hungarian language, $25.9 \%$ in Romanian language, and $24.1 \%$ in mathematics. The average level group included $46.2 \%$ of the students regarding mathematics, $40.2 \%$ regarding Romanian language, and 35\% regarding Hungarian language. On the other hand, one third of the examined population can be classified into the category of "low performance" in almost all measurement areas: $35.5 \%$ in Hungarian language, $33.9 \%$ in Romanian language, and $29.7 \%$ in mathematics.

Examining the results, we found a significant correlation between competence in Hungarian language and settlement type. $68.8 \%$ of students in schools operating in small settlements fall into the low performance 
category, in contrast to $31.3 \%$ in urban schools. The average performance category includes $53.6 \%$ of students from schools in small settlements, and $46.4 \%$ of students from the urban ones. As for high performance, $39.7 \%$ of village schoolchildren and $60.3 \%$ of urban school children fall into this category.

Analysing the Romanian language measurement results and the settlement types, we can also establish a strong significant correlation. $68.9 \%$ of the low achievement category is made up of students in villages, while $31.1 \%$ is made up of students in urban schools. There is no significant difference between the settlement types in the average performance category, whereas in the high-performance category we can see that $45.4 \%$ are students from villages and $54.6 \%$ are students from towns. With regard to mathematics, $76.1 \%$ of the low achievement category is made up of students living in villages, while $23.9 \%$ is made up of urban students. In the average performance category, $53.8 \%$ of the students live in villages, $46.2 \%$ in urban areas, while in the high performance category, $34 \%$ of the students live in villages and $66 \%$ are urban students.

Table 2. Relationships between settlement type and achievement

\begin{tabular}{lllll}
\hline & Settlement type & low achieving & average achieving & high achieving \\
\hline $\begin{array}{l}\text { Hungarian } \\
\text { language }\end{array}$ & Village & $\underline{68,8 \%}$ & $53,6 \%$ & $39,7 \%$ \\
\cline { 2 - 5 } $\begin{array}{l}\text { Romanian } \\
\text { language }\end{array}$ & City & $\underline{31,3 \%}$ & $46,4 \%$ & $\underline{60,3 \%}$ \\
\hline \begin{tabular}{l} 
Mathematics \\
\cline { 2 - 5 }
\end{tabular} & Village & $\underline{68,9 \%}$ & $51 \%$ & $45,4 \%$ \\
\cline { 2 - 5 } & Vity & $\underline{31,1 \%}$ & $49 \%$ & $\underline{54,6 \%}$ \\
\hline
\end{tabular}

$\mathrm{P}=0,000$, adj. resid $>3, \mathrm{~N}=1054$

We found that there are indeed significant differences in all three testing areas depending on the type of settlement: especially in the low achievement category there is a much higher proportion of students from small settlements than from urban schools.

We were also searching for a relationship between settlement type and resilience. A resilient school was defined based on aggregate school averages. We also examined the proportion of students with low SES who were resilient. We found a significant correlation for students of urban schools with disadvantaged composition in all three competency measurement results. Where students can be classified into the lower quarter of the sample based on their socioeconomic status, 6.8\% are resilient regarding Hungarian language, 6.3\% in mathematics and $12.2 \%$ in Romanian language. In villages, resilience can be detected only in the Romanian language levelling results $(43.7 \%)$.

In the three studied areas, the proportion of resilient students differs according to the type of settlement. In Hungary, students in smaller settlements have a higher chance of becoming resilient, whereas in Romania this was only confirmed in the case of the Romanian language competency test. This can also be explained by the fact that the Romanian language measurement results are very low both in urban and small school schools in the region (Kádár, 2016), and in smaller schools students work harder to achieve better.

\section{Discussion}

Multivariate logistic regression was used to explain the Romanian language and mathematics competency measurement results. We included explanatory variables in three steps. The variables are dummy variables, coded 0 to 1 . In the first round, we included the educational level of parents among the explanatory variables. The parental educational level is one of the most decisive factors of pupil achievement (Bourdieu, 1986; Bradly \& Corwyn, 2002). The father's level of education has a strong influence on the educational attainment of the next generation, but the educational attainment of mothers is in many cases higher than that of fathers (Pusztai, 2004). Research in Hungary has shown the decisive role of the mother's educational level. School results are more closely related to the mother's level of education than to the father's (Csapó, 1998; Róbert, 2004). In our case, we found that the mother's high school diploma and higher education explain resilience in the case of the Romanian language too. Students having mothers and fathers with a high school diploma and students having fathers with a tertiary education degree are significantly more likely to be resilient in mathematics. In the second step, we included explanatory variables related to the family's financial situation. We examined whether the mother and father have a permanent job and whether the subjective financial situation of the family may explain the resilience. In our sample, no significant effect can be detected in the case of Romanian language. If the mother has a permanent job, her permanent employment has a positive effect on mathematical resilience. 
In the third step, the settlement type was involved. In the case of Romanian language, the effect of the settlement type could not be detected. Regarding effectiveness in mathematics, urban students are significantly more resilient. Our results are partly consistent with research (Garami, 2009) that sheds light on the fact that small settlement schools are less likely to achieve outstanding results. According to Patakfalvi-Cirják, Papp Z. \& Neumann (2018), resilient schools are more likely to be located in small settlements / villages. We can see that based on our results, in the case of the Romanian language competence test, resilience is typical in villages, while in the case of the mathematics competence measurements, students in low SES schools are resilient as shown in Table 3.

Table 3. Multistage logistic regression analysis of the factors influencing the Romanian language and mathematics competence measurement effectiveness

\begin{tabular}{|c|c|c|c|c|c|c|}
\hline & \multicolumn{3}{|c|}{ Romanian language resilient } & \multicolumn{3}{|c|}{ Mathematics resilient } \\
\hline & 1. step & 2. step & 3. step & 1. step & 2. step & 3. step \\
\hline & $\operatorname{Exp}(B)$ & $\operatorname{Exp}(B)$ & $\operatorname{Exp}(B)$ & $\operatorname{Exp}(B)$ & $\operatorname{Exp}(\mathrm{B})$ & $\operatorname{Exp}(\mathrm{B})$ \\
\hline $\begin{array}{l}\text { high_school } \\
\text { diploma_mother }\end{array}$ & $1.443 *$ & $1.463 *$ & $1.516^{*}$ & $1.613 * *$ & $1.495^{*}$ & .8951. \\
\hline $\begin{array}{l}\text { high_school } \\
\text { diploma_father }\end{array}$ & .801 & .798 & .787 & $.542 *$ & $.543 *$ & .618 \\
\hline graduate_mother & $.625^{*}$ & .654 & .666 & 1.336 & 1.274 & 1.010 \\
\hline graduate_father & 1.440 & 1.471 & 1.515 & $2.833 * * *$ & $2.768 * * *$ & $2.088^{* *}$ \\
\hline permanent job_mother & & .999 & 1.020 & & $1.542 * *$ & 1.169 \\
\hline permanent job_father & & 1.069 & 1.062 & & .931 & 1.024 \\
\hline subjective well-being & & $.721 *$ & $.725^{*}$ & & .959 & .866 \\
\hline Settlement type & & & .374 & & & $7.296^{* * *}$ \\
\hline
\end{tabular}

\section{Conclusions}

In our study, we analysed the correlations between school effectiveness, family background and settlement type. The analysis highlights that disadvantaged schools are more prevalent in small settlements. The proportion of resilient students varies in different competency measurement areas. However, only in the case of the Romanian language levelling test was it proved that schools in villages have a higher chance of developing resilience. The effect of the settlement type on resilience can be detected in the mathematics competence test results. Resilience, in the case of Romanian language, is explained by the mother's education level, while in the case of mathematics it is explained by subjective well-being and the father's higher education. Adverse regional conditions amplify the impact of adverse family and school backgrounds on performance. The results are similar regarding Hungarian language and mathematics in urban schools, but different regarding Romanian language.

\section{References}

Bacskai, K. (2016). What is the Worth of a Teacher if Central-European?: Effective Teachers in Two Central-European Countries Teaching Low-Status Students. In E. Berghauer-Olasz, I. Greba, É. Hutterer, K. Pallay (Eds.) Innovatív módszerek a pedagógiai-pszichológiai gyakorlatban Ukrajna európai integrációjának tükrében. Kálvin Nyomda, 6269.

Ball, S. (2003). Class strategies and the education market: the Middle classes and social advantage. Routledge/Falmer Press.

Barabás, A. (2019a). A negyedik osztályos országos kompetenciamérés Kovászna megyei eredményei. [The 4th Graders’ National Competence Measurement Results in Kovaszna County] PedActa, 2. http://padi.psiedu.ubbcluj.ro/pedacta/article_9_2_6.pdf

Barabás, A. (2019b). The Challenges and Possibilities of the Preparatory Class. Astrasalvensis, 2, $261-274$. https://astrasalvensis.eu/2019-2/

Barabás, A. (2020). The Effects of Extracurricular and Extraschool Activities on School Performance. Journal of Pedagogy, 1, 173- 192. http://revped.ise.ro/en/rp-2020-1/) 
Behtoui, A., \& Neergaard, A. (2016). Social Capital and the Educational Achievement of Young People in Sweden. British Journal of Sociology of Education, 37(7), 947-969.

Bourdieu, P. (1986). The Forms of Capital. In J. G. Richardson (Eds.), Handbook of theory and research for the sociology of education, 241-58. Greenwood Press.

Bradley, R. \& Corwyn, R. (2002). Socioeconomic status and child development. Annual Review of Psychology, 371-399.

Csapó, B. (1998). Az iskolai tudás. [School knowledge]. Osiris Kiadó.

Ceglédi, T. (2017). Reziliencia és felsőoktatás. Beteljesül a reziliencia ígérete vagy élesednek a társadalmi egynlőtlenségek a felsőoktatásban? [Resilience and higher education. The promise of resilience is fulfilled or social inequalities in higher education are exacerbated?] Doktori ( $\mathrm{PhD})$ értekezés

Coleman, J. (1966). Equality of Educational Opportunity. US Government Printing Office.

Fehérvári, A. (2016). Iskolai eredményesség és hátrányos helyzet. [School performance and disadvantage]. In M. Szemerszki (Eds.), Hátrányos helyzet és iskolai eredményesség. Oktatáskutató és Fejlesztő Intézet.

Forray, R. K. \& Kozma, T. (2010). Társadalmi egyenlőség és kulturális identitás? [Social equality and cultural identity?] Képzés és Gyakorlat, 2, 3-23.

Garami, E. (2009). A legkiválóbb középiskolák területi különbségei. [Territorial differences between the best high schools]. Educatio, 18(2), 241-250.

Garami, E. (2014). Kistérségi jellemzők és az oktatás eredményessége. [Micro-regional characteristics and effectiveness of education]. Educatio, 23(3), 424-437.

Horn, D \& Keller, T \& Róbert, P (2016). Early tracking and competition: a recipe for major inequalities in Hungary. In Hans-Peter, Blossfeld; Sandra, Buchholz; Jan, Skopek; Triventi, Moris (Eds.) Models of secondary education and social inequality : an international comparison. Edward Elgar, 129-148.

Imre, A. (2004). Kistelepülési iskolák és eredményesség. [Small town schools and effectiveness] In Simon, M. (Eds.), Válaszol az iskola, 195-216. Országos Közoktatási Intézet.

Kádár, E. (2016). A magyar nyelv tantárgy tartalma és oktatása a romániai oktatásszabályozási keretben, [The content and teaching of the subject of the Hungarian language in the Romanian educational framework]. Nemzeti Kisebbségkutató Intézet,

https://www.academia.edu/39035622/A_magyar_nyelv_tantárgy_tartalma_és_oktatása_a_romániai_oktatásszabályo zási_keretben

Kiss, T. \& Barna, G. (2012). Népszámlálás 2011. Erdélyi magyar népesedés a XXI. század első évtizedében, [Census 2011. Hungarian population in Transylvania in the XXI. in the first decade of the twentieth century]. Nemzeti Kisebbségkutató Intézet.

Kitchen, H., Fordham, E., Henderson, K., Looney, A., Maghnouj, S. (2017). OECD Reviews of Evaluation and Assessment in Education, OECD Publishing.

Kozma, T. (1988). Iskola és település. [School and settlement]. Akadémiai Kiadó.

Kozma, T. (2003). Kisebbségi oktatás Közép-Európában. [Minority education in Central Europe]. Oktatáskutató Intézet.

Manolescu, D.\& Potolea, M. (2006). Teoria si metodologia curriculumului [Curriculum theory and methodology], Ministerul Educaţiei şi Cercetării.

Papp, Z. A. (2012). Kisebbségi magyarok oktatási részvételének értelmezési lehetőségei. [Possibilities of interpreting the educational participation of minority Hungarians]. Educatio, 21(3), 3-23.

Papp, Z. A. (2017). Kisebbségi magyar oktatás: értelmezések, adatok. [Minority Hungarian education: interpretations, data]. Habilitációs kézirat

Patakfalvi-Cirják, Á., Papp Z., A. \& Neumann, E. (2018). Az iskola nem sziget. Oktatási és társadalmi reziliencia multietnikus környezetben. [School is not an island. Educational and social resilience in a multiethnic environment]. Educatio, 27(3), 747-480.

Pusztai, G. (2004). Iskola és közösség -Felekezeti középiskolások az ezredfordulón. [School and CommunityDenominational high school students at the turn of the millennium]. Gondolat Kiadó.

Pusztai, G. (2015). Pathways to Success in Higher Education. Rethinking the Social Capital Theory in the Light of Institutional Diversity. Higher Education Research and Policy (herp), 7. Peter Lang Edition.

Pusztai, G., \& Bacskai, K. (2015). Parochial schools and PISA effectiveness in three Central European Countries. Acta Universitatis Sapientiae, 5(2), 145.

Széll, K. (2015). Iskolai eredményesség a hátrányos helyzet tükrében. [School performance in light of disadvantage]. Educatio, 24(1), 140-147.

Széll, K. (2018). Iskolai légkör és eredményesség. [School atmosphere and effectiveness]. Belvedere Meridionale.

Singer, F. (2013). Romanian Research in Education: Where to? The Journal of Science Policy and Scientometrics, 2(4). 
Zoller, K., \& Bacskai, K. (2020). Teacher work and jobsatisfaction among Romanian lower secoundary teachers. Central European Journal of Educational Research, 2(2), 93-100. https://doi.org/10.37441/CEJER/2020/2/2/7918 (C) 2020 by the authors. Submitted for possible open access publication under the terms and conditions of the Creative Commons Attribution (CC BY) license (http://creativecommons.org/licenses/by/4.0/). 